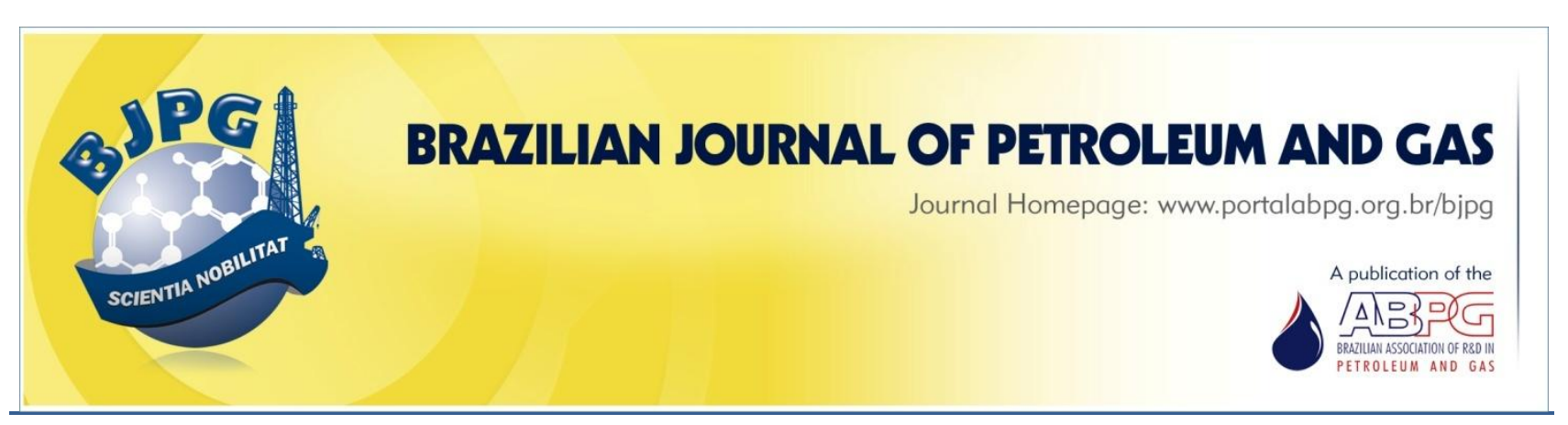

\title{
AN EXPERIMENTAL WORK TO EVALUATE CORRELATIONS FOR WELL-CEMENTING HYDRAULICS CALCULUS ON FIELD APPLICATIONS
}

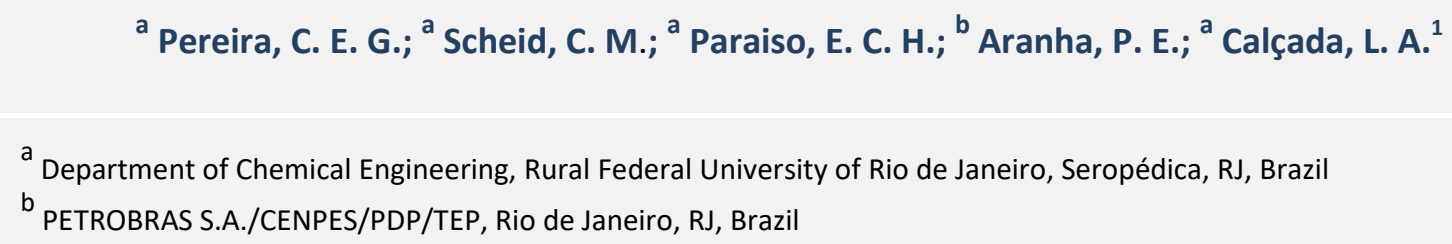

Received: 22.09.2016 / Revised: 20.06.2017 / Accepted: 20.06.2017 / Published on line: 18.07.2017

\begin{abstract}
In narrow operational window scenarios of the pre-salt layer, a proper control of slurry hydraulic behavior is a prime necessity. This work aims to present pressure drop experimental data obtained in pipe and annular flow of different cement slurries formulations. Data analysis includes evaluation of friction factor correlations, rheological analysis, and equivalent diameter considerations (for annular flow). The set of equations proposed was, then, used to simulate well-cementing operations and compared to real field data. Improved predictions supported the adoption of the proposed methodology in the cementing design software used by a major operator in Brazil.
\end{abstract}

\section{KEYWORDS}

pre-salt layer; cement slurry; pressure drop; case study

\footnotetext{
${ }^{1}$ To whom all correspondence should be addressed.

Address: Department of Chemical Engineering, Rural Federal University of Rio de Janeiro, BR-467, Km7, Campus of UFRRJ, Seropédica, Rio de Janeiro, Brazil.

ZIP Code: 23890-000 | Telephone/Fax: +55 21 37878742/+55 21 37873750|e-mail: calcada@ufrri.br doi:10.5419/bjpg2017-0005
} 


\section{INTRODUCTION}

In the well construction process, cementing is one important operation. This importance is due mainly to the zonal isolation provided by it. This zonal isolation enables the oil well integrity to be established by preventing fluid migration into the annular region. Moreover, cementing operation keeps the mechanical stability of wells, holds the casing in place, and protects the casing from corrosive formation fluids (Miranda, 2008).

There are two basic cementing processes: primary and squeeze cementing. The former is a process whereby the cement slurry is pumped downhole through the inner side of the casing column, and, then, through the annular region. This region is formed by the rock and the outer surface of the casing column. The latter is a process that, among many purposes, repairs a primary cementing job that had failed (Nelson, 1990).

To perform well primary cementing and avoid accidents, some issues must be taken into account. One of them is the downhole pressure control. Pressure drop prediction for cement slurry flow is one of the factors that contribute to this control. In conventional operations, the fluid pumping pressure should be maintained between pore pressure and fracture pressure to prevent an unwanted influx of formation fluids into the wellbore, causing kicks or even blowouts (Lake \& Mitchel, 2006; Nelson, 1990). In this context, the influence of hydrostatic pressure and friction loss on predicting pumping pressure is different for each kind of oil well for vertical or deviated wells. When cementing on a deviated and extendedreach well (ERW), the hydrostatic pressure is lower than on a vertical one of the same length. This makes the friction loss more important and its prediction even more essential.

This work focuses on the evaluation of relevant equations to predict pressure drop, such as: friction factor correlations, hydraulic diameter, and rheological models. It evaluates two different cement slurry formulations with different densities. To predict pressure losses in primary cementing processes correctly, a fluid flow loop was designed with a real oil well dynamic similarity. The flow loop was able to provide experimental data regarding the pressure drop and flow rate in the circular and annular regions. The goal of this research is to evaluate the relevant correlations, abovementioned, to predict pressure drop by using the data achieved in the experiments. The correlations evaluated in the laboratory were the rheological models, the friction factor, and the hydraulic diameter. We also validated those correlations using a set of simulated and real oil well experimental data. The simulated data were compared with two real cases; case study 1 from an onshore real deviated and extended-reach well, ERW; and a case study 2 from Campos Basin well in a narrow operational window system.

The experimental results were analyzed applying the set of equations evaluated in a real simulator. The simulated results were compared with actual data obtained during the drilling of oil wells in Brazil.

\section{THEORY}

\subsection{Rheological models}

Bourgoyne et al. (1991) reported that the rheological models used in the drilling and cementing processes may be fitted by the Bingham model (Equation 1) and the power law model (Equation 2). These models are also the most commonly used in cementing, according to Nelson (1990).

$$
\begin{aligned}
& \tau=V P_{B} \stackrel{\&}{\gamma}+L E_{B} \\
& \tau=k \gamma^{n}
\end{aligned}
$$

In addition, the Herschel-Buckley model, given by Eq. 3, accounts for the characteristics of both Herschel-Buckley and Power Law models.

$$
\tau=k_{H B} \gamma^{n_{H B}}+L E_{H B}
$$

\subsection{Friction factor}

The experimental Fanning friction factor can be determined with Eq. 4, which is obtained by replacing the pressure loss equation in the modified Bernoulli equation.

$$
f=\frac{\Delta P D}{2 \rho L\langle v\rangle^{2}}
$$




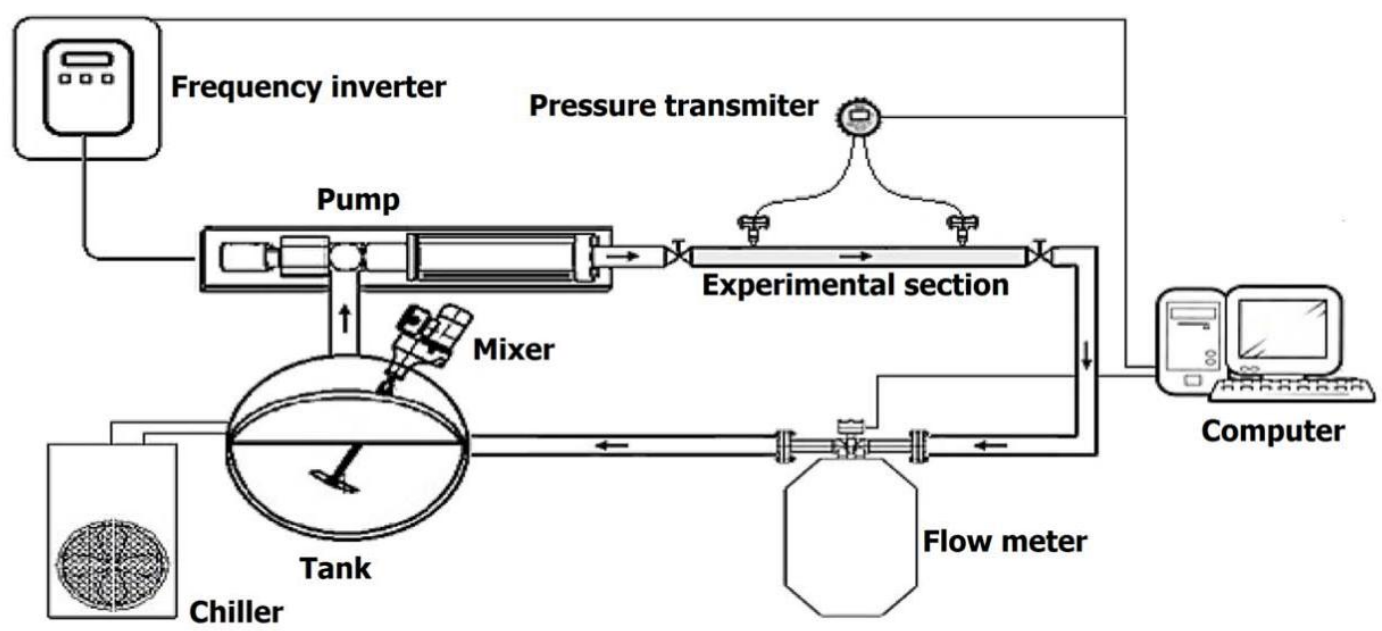

Figure 1. Experimental unit for cement slurries flow (adapted from Paraiso, 2011).

Nelson (1990) provided, for non-Newtonian fluids, the friction factor equations, in laminar flow, developed for specific rheological models (Table A.1, Appendix). For non-Newtonian fluids in turbulent flow, there are several proposed correlations (Table A.2, Appendix), which were detailed by Paraiso (2011). The equations presented in Table A.2 were used in this work for the three rheological models. The exceptions are the models proposed by Darby et al. (1992) and Darby and Melson (1981), which are applied only with the Bingham and Herschel Buckley models, since both are used for yield stress fluids.

\subsection{Hydraulic diameter correlations for annular ducts}

Hydraulic diameter correlations are either analytical or empirical, and provide values of characteristic diameters that can represent the annular duct as a circular one. For the slot and the hydraulic radius correlations, Bourgoyne et al. (1991) presented a model described by Eq. 5 and 6 .

$$
\begin{aligned}
& D_{H_{1}}=0.816\left(D_{2}-D_{1}\right) \\
& D_{H_{2}}=\left(D_{2}-D_{1}\right)
\end{aligned}
$$

\section{EXPERIMENTAL DESCRIPTION}

\subsection{Experimental Apparatus}

The experimental apparatus flow loop shown in Fig. 1 consisted of a system operating in a closed circuit. Paraiso (2011) provided the specific characteristics of this system. The experimental sections were composed of a circular tube $1 "$ in diameter and two concentric annular with the following outer to inner diameter ratios: Annular 1 $\left(1 \frac{1}{2}{ }^{\prime \prime}-1 "\right)$ and Annular $2\left(1 \frac{1}{4}{ }^{\prime \prime}-3 / 4^{\prime \prime}\right)$. Differential pressure, mass flow, temperature, and density of the slurries were measured.

\subsection{Analyzed fluids}

Two cement slurries composed of a mixture consisting of G-class cement were evaluated: fresh water and additives (mid-temperature retarder and antifoam agent). Silica (325 mesh) was further added to Slurry 2.

\subsection{Experimental procedure}

The fluids of interest were pumped through the test section varying flow rate. Pressure drop was measured in real time. Also, during pressure drop tests, rheological data were obtained in a laboratory FANN 35A viscometer, which evaluates viscosity at six pre-determined shear rates. 
Table 1. Characteristics of the fluids and ducts studied.

\begin{tabular}{lcc}
\hline Composition & $\begin{array}{c}\text { Evaluated } \\
\text { temperatures }\end{array}$ & Analyzed ducts \\
(Slurries 1 and 2) & temperis \\
\hline
\end{tabular}

Circular (1")

G-class cement;

Fresh water;

Antifoam agent;

$\left(1 \frac{1}{2 \prime \prime}-1^{\prime \prime}\right)$

Silica 325\# (added only to Slurry 2).

Annular 2

$\left(1 \mathbf{1}^{\prime \prime}-3 / 4^{\prime \prime}\right)$

Table 2. Average rheological parameters obtained.

\begin{tabular}{|c|c|c|c|c|c|c|c|c|c|c|c|}
\hline \multirow{2}{*}{$\begin{array}{l}\text { Cement } \\
\text { Slurries }\end{array}$} & \multirow{2}{*}{$\begin{array}{c}\mathrm{T} \\
\left({ }^{\circ} \mathrm{C}\right)\end{array}$} & \multicolumn{3}{|c|}{ Power law } & \multicolumn{3}{|c|}{ Bingham } & \multicolumn{4}{|c|}{ Herschel-Buckley } \\
\hline & & $\mathrm{n}$ & $\begin{array}{c}\mathrm{K} \\
\left(\mathrm{Pa} . \mathrm{s}^{\mathrm{n}}\right)\end{array}$ & $\mathrm{R}^{2}$ & $\begin{array}{c}\mathrm{LE} \\
(\mathrm{Pa})\end{array}$ & $\begin{array}{c}\text { VP } \\
\text { (Pa.s) }\end{array}$ & $\mathrm{R}^{2}$ & $\mathrm{n}$ & K $\left(\right.$ Pa.s s $\left.^{n}\right)$ & LE (Pa) & $\mathrm{R}^{2}$ \\
\hline \multirow{3}{*}{$\begin{array}{l}\text { Cement } \\
\text { Slurry } 1\end{array}$} & 15 & 0.38 & 1.69 & 0.923 & 3.90 & 0.036 & 0.996 & 0.89 & 0.08 & 3.37 & 0.999 \\
\hline & 25 & 0.30 & 1.94 & 0.889 & 3.82 & 0.023 & 0.996 & 0.90 & 0.05 & 3.36 & 0.998 \\
\hline & 60 & 0.18 & 5.84 & 0.925 & 9.01 & 0.020 & 0.996 & 0.61 & 0.35 & 7.47 & 0.987 \\
\hline \multirow{3}{*}{$\begin{array}{l}\text { Cement } \\
\text { Slurry } 2\end{array}$} & 15 & 0.38 & 2.45 & 0.900 & 5.47 & 0.055 & 0.998 & 0.94 & 0.09 & 5.03 & 0.999 \\
\hline & 25 & 0.29 & 3.41 & 0.834 & 6.12 & 0.038 & 0.997 & 1.00 & 0.04 & 6.13 & 0.997 \\
\hline & 60 & 0.21 & 5.75 & 0.864 & 9.14 & 0.027 & 0.982 & 0.81 & 0.13 & 8.33 & 0.990 \\
\hline
\end{tabular}

Characteristics of the fluids and of the ducts studied are summarized in Table 1 . The percentage of each component is not indicated due to industrial secrecy.

\section{DATA AND RESULTS}

\subsection{Evaluation of rheological behaviour}

During the flow test the rheological data were analyzed and the average values are presented in Table 2. The correlation coefficients $\left(R^{2}\right)$ are used in the analysis of model adequacy. As expected, the Herschel-Buckley model showed the best correlation coefficient. For analyzed cement slurries, the Bingham model also showed good correlation.

\subsection{Evaluation of hydraulic diameter correlations}

To evaluate hydraulic diameter correlations, data of experimental and theoretical pressure loss versus flow rate were used. These data were obtained based on the flow of cement slurries in laminar regime. To illustrate the evaluation, results obtained for Annular 1 are shown in Fig. 2, using the Herschel-Buckley model and the experimental data flow, Slurry 2.

Fig. 2 shows that $\mathrm{DH}_{2}$ correlation (hydraulic radius) was the one closest to the experimental results for Cement Slurry 2 using the HerschelBuckley model. For the two slurries studied and still using the Bingham and power law models, the same behaviour analysis was performed also in the other annular. The average absolute percentage 


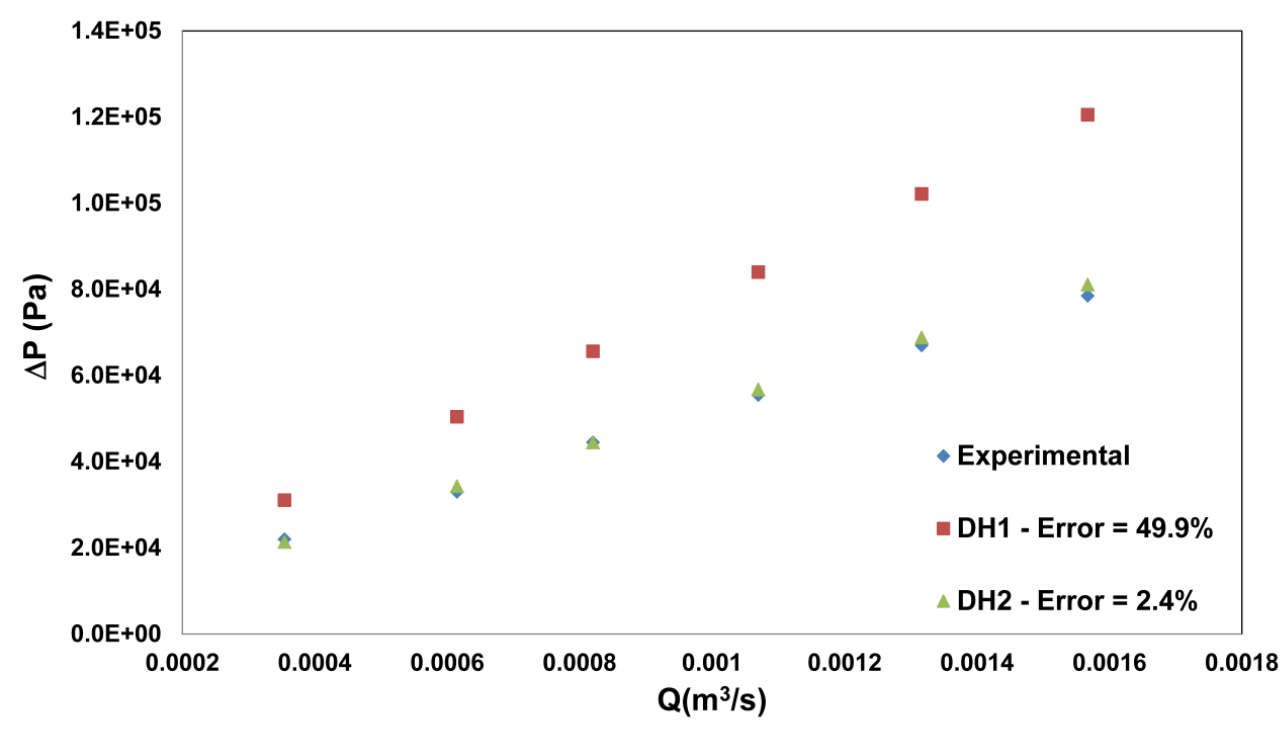

Figure 2. Evaluation of hydraulic diameter equations in terms of pressure drop in Cement Slurry 2 flow at $25^{\circ} \mathrm{C}$, in Annular duct $1\left(1 \frac{12 \prime}{\prime \prime}-1^{\prime \prime}\right)$, Herschel-Buckley model.

errors of the hydraulic diameter correlations are shown in Table 3. In this table, the absolute percentage errors less than $25 \%$ are highlighted. The results presented for each annular and hydraulic radius correlation are the average errors calculated for temperatures of 15,25 and $60^{\circ} \mathrm{C}$. An analysis of Table 3 shows that the $\mathrm{DH}_{2}$ correlation achieved better results using the Bingham and Herschel-Buckley models.

\subsection{Evaluation of friction factor correlations}

Fig. 3 shows a comparison between the experimental data and the one performed with the friction factor correlation. Looking at Fig. 3, one can see that, when using the Herschel-Buckley model, a satisfactory estimate was obtained for the friction factor in turbulent flow, using $\mathrm{DH}_{2}$ (hydraulic radius) combined with the Ellis and George (1977) correlation. The same graphic analysis was performed for the other annular and circular ducts at 15,25 , and $60{ }^{\circ} \mathrm{C}$ still using the Bingham and the Power law models for the two slurries studied. The average absolute percentage errors of friction factor correlations are shown in Tables 4 and 5. In these tables, the absolute percentage errors of less than $25 \%$ are highlighted.

Table 3. Average absolute percentage error of hydraulic diameter for cement slurries.

\begin{tabular}{|c|c|c|c|c|c|c|c|c|}
\hline \multirow{2}{*}{$\begin{array}{l}\text { Cement } \\
\text { Slurries }\end{array}$} & \multirow[t]{2}{*}{ Rheological models } & \multirow[t]{2}{*}{$\mathrm{T}\left({ }^{\circ} \mathrm{C}\right)$} & \multicolumn{2}{|c|}{$\begin{array}{l}\text { Annular } 1 \\
\left(11^{\prime \prime}-1^{\prime \prime}\right)\end{array}$} & \multicolumn{2}{|c|}{$\begin{array}{c}\text { Annular } 2 \\
\left(11^{\prime \prime}-3 / 4^{\prime \prime}\right) \\
\end{array}$} & \multicolumn{2}{|c|}{$\begin{array}{c}\text { Average } \\
\text { error }\end{array}$} \\
\hline & & & $\mathrm{DH}_{1}$ & $\mathrm{DH}_{2}$ & $\mathrm{DH}_{1}$ & $\mathrm{DH}_{2}$ & $\mathrm{DH}_{1}$ & $\mathrm{DH}_{2}$ \\
\hline \multirow{3}{*}{$\begin{array}{l}\text { Cement } \\
\text { Slurry } 1\end{array}$} & Power law & \multirow{3}{*}{$15-60$} & 30.6 & 45.4 & 28.2 & 46.5 & 29.4 & 46.0 \\
\hline & Bingham & & 40.7 & 11.2 & 26.0 & 15.3 & 33.4 & 13.3 \\
\hline & Herschel-Buckley & & 21.4 & 17.2 & 16.1 & 20.5 & 18.8 & 18.9 \\
\hline \multirow{3}{*}{$\begin{array}{l}\text { Cement } \\
\text { Slurry } 2\end{array}$} & Power law & \multirow{3}{*}{$15-60$} & 24.7 & 44.9 & 23.1 & 37.6 & 23.9 & 41.3 \\
\hline & Bingham & & 56.6 & 6.9 & 65.3 & 13.7 & 61.0 & 10.3 \\
\hline & Herschel-Buckley & & 52.2 & 5.4 & 48.9 & 6.7 & 50.6 & 6.1 \\
\hline
\end{tabular}




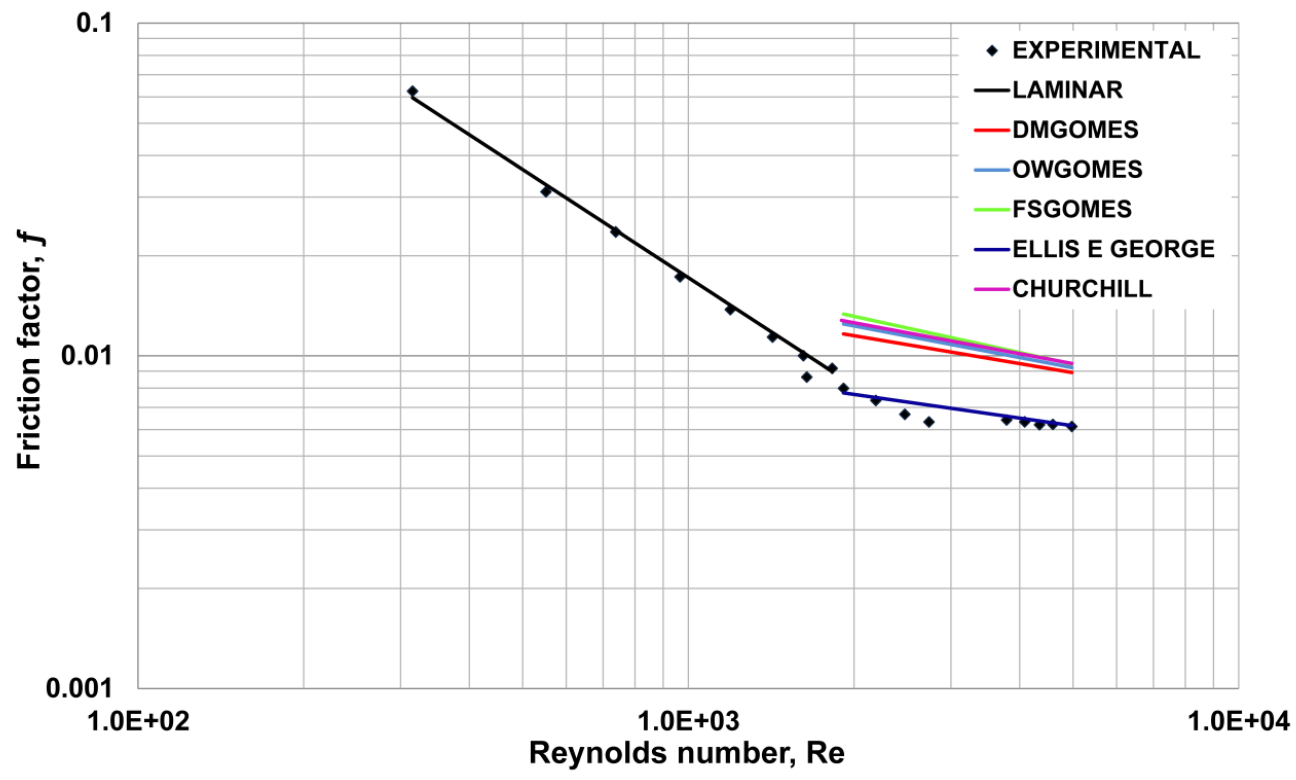

Figure 3. Friction factor versus Reynods number of Cement Slurry 2, Annular 1, at 25 oC, Herschel-Buckley model, and $\mathrm{DH}_{2}$ correlation to calculate the hydraulic diameter.

Table 4. Average absolute percentage error of friction factor correlations for Cement Slurry 1 at 15,25, and $60{ }^{\circ} \mathrm{C}$.

\begin{tabular}{|c|c|c|c|c|c|c|c|c|}
\hline \multirow{2}{*}{\multicolumn{2}{|c|}{$\begin{array}{l}\text { Friction factor correlations } \\
\text { Cement Slurry } 1 \\
\left(15,25,60^{\circ} \mathrm{C}\right)\end{array}$}} & \multirow{2}{*}{$\begin{array}{c}\text { Circular } \\
\text { (1") }\end{array}$} & \multicolumn{2}{|c|}{$\begin{array}{l}\text { Annular } 1 \\
\left(11^{\prime \prime}-1^{\prime \prime}\right)\end{array}$} & \multicolumn{2}{|c|}{$\begin{array}{c}\text { Annular } 2 \\
\left(11 / 4^{\prime \prime}-3 / 4^{\prime \prime}\right)\end{array}$} & \multicolumn{2}{|c|}{ Average error } \\
\hline & & & $\mathrm{DH}_{1}$ & $\mathrm{DH}_{2}$ & $\mathrm{DH}_{1}$ & $\mathrm{DH}_{2}$ & $\mathrm{DH}_{1}$ & $\mathrm{DH}_{2}$ \\
\hline \multirow{6}{*}{ 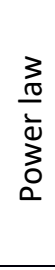 } & Laminar & 15.9 & 30.6 & 45.4 & 28.2 & 46.5 & 29.4 & 46.0 \\
\hline & DM Gomes & 36.5 & 39.4 & 51.2 & 32.9 & 45.9 & 36.2 & 48.6 \\
\hline & OW Gomes & 51.0 & 52.8 & 62.0 & 46.3 & 56.7 & 49.6 & 59.4 \\
\hline & FS Gomes & 49.5 & 51.5 & 61.0 & 45.5 & 56.3 & 48.5 & 58.7 \\
\hline & Ellis and George & 10.8 & 13.9 & 25.5 & 14.5 & 24.0 & 14.2 & 24.7 \\
\hline & Churchill & 20.6 & 18.0 & 12.3 & 17.9 & 12.5 & 18.0 & 12.4 \\
\hline \multirow{6}{*}{$\begin{array}{l}\frac{E}{N} \\
\frac{E}{60} \\
\stackrel{\frac{L}{0}}{\infty}\end{array}$} & Laminar & 10.7 & 40.7 & 11.2 & 26.0 & 15.3 & 33.4 & 13.3 \\
\hline & Darby and Melson & 16.2 & 11.6 & 24.3 & 11.7 & 22.7 & 11.7 & 23.5 \\
\hline & Tomita & 22.9 & 55.7 & 19.8 & 57.6 & 22.7 & 56.7 & 21.3 \\
\hline & Darby et al. & 26.3 & 24.4 & 40.3 & 23.3 & 38.8 & 23.8 & 39.6 \\
\hline & Ellis and George & 29.4 & 16.6 & 13.1 & 21.7 & 12.4 & 19.2 & 12.8 \\
\hline & Churchill & 38.8 & 64.4 & 32.8 & 72.8 & 39.7 & 68.6 & 36.3 \\
\hline \multirow{6}{*}{ 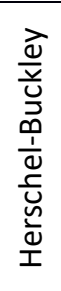 } & Laminar & 10.7 & 21.4 & 17.2 & 16.1 & 20.5 & 18.8 & 18.8 \\
\hline & DM Gomes & 16.5 & 35.2 & 18.9 & 40.8 & 13.7 & 38.0 & 16.3 \\
\hline & OW Gomes & 13.5 & 41.5 & 24.0 & 39.8 & 15.5 & 40.7 & 19.8 \\
\hline & FS Gomes & 13.0 & 45.4 & 26.1 & 42.3 & 16.1 & 43.9 & 21.1 \\
\hline & Ellis and George & 8.5 & 8.6 & 15.9 & 14.8 & 15.0 & 11.7 & 15.5 \\
\hline & Churchill & 32.2 & 49.7 & 19.5 & 57.4 & 26.9 & 53.6 & 23.2 \\
\hline
\end{tabular}


Table 5. Average absolute percentage error of friction factor correlations for Cement Slurry 2 at 15,25 , and $60{ }^{\circ} \mathrm{C}$.

\begin{tabular}{|c|c|c|c|c|c|c|c|c|}
\hline \multirow{2}{*}{\multicolumn{2}{|c|}{$\begin{array}{l}\text { Friction factor correlations } \\
\text { Cement Slurry } 2(15,25 \\
\left.60^{\circ} \mathrm{C}\right)\end{array}$}} & \multirow[t]{2}{*}{$\begin{array}{c}\text { Circular } \\
\text { (1") }\end{array}$} & \multicolumn{2}{|c|}{$\begin{array}{l}\text { Annular } 1 \\
\left(11^{\prime \prime}-1^{\prime \prime}\right)\end{array}$} & \multicolumn{2}{|c|}{$\begin{array}{c}\text { Annular } 2 \\
\left(11^{\prime \prime}-3 / 4^{\prime \prime}\right)\end{array}$} & \multicolumn{2}{|c|}{ Average error } \\
\hline & & & $\mathrm{DH}_{1}$ & $\mathrm{DH}_{2}$ & $\mathrm{DH}_{1}$ & $\mathrm{DH}_{2}$ & $\mathrm{DH}_{1}$ & $\mathrm{DH}_{2}$ \\
\hline \multirow{6}{*}{$\begin{array}{l}\frac{3}{10} \\
\frac{1}{\grave{亠}} \\
\sum_{0} \\
0\end{array}$} & Laminar & 18.8 & 24.7 & 44.9 & 23.1 & 39.1 & 23.9 & 42.0 \\
\hline & DM Gomes & 35.9 & 34.0 & 45.5 & 35.2 & 47.7 & 34.6 & 46.6 \\
\hline & OW Gomes & 48.9 & 46.5 & 56.0 & 50.3 & 60.0 & 48.4 & 58.0 \\
\hline & FS Gomes & 48.0 & 44.5 & 55.1 & 48.7 & 58.9 & 46.6 & 57.0 \\
\hline & Ellis and George & 12.7 & 15.5 & 25.9 & 11.0 & 19.4 & 13.2 & 22.7 \\
\hline & Churchill & 11.9 & 18.5 & 8.9 & 26.3 & 8.7 & 22.4 & 8.8 \\
\hline \multirow{6}{*}{ 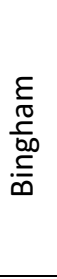 } & Laminar & 12.3 & 56.6 & 7.9 & 64.6 & 13.7 & 60.6 & 10.8 \\
\hline & Darby and Melson & 16.2 & 11.2 & 21.8 & 12.3 & 16.2 & 11.7 & 19.0 \\
\hline & Tomita & 21.2 & 67.4 & 28.7 & 77.4 & 37.2 & 72.4 & 33.0 \\
\hline & Darby et al. & 33.7 & 21.6 & 38.6 & 17.0 & 33.4 & 19.3 & 36.0 \\
\hline & Ellis and George & 8.5 & 23.9 & 9.2 & 30.6 & 8.5 & 27.3 & 8.8 \\
\hline & Churchill & 37.6 & 70.6 & 42.9 & 84.9 & 50.6 & 77.7 & 46.8 \\
\hline \multirow{6}{*}{ 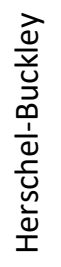 } & Laminar & 12.3 & 52.2 & 5.4 & 49.1 & 6.8 & 50.7 & 6.1 \\
\hline & DM Gomes & 25.1 & 73.1 & 35.8 & 66.2 & 30.9 & 69.6 & 33.4 \\
\hline & OW Gomes & 25.9 & 80.1 & 40.7 & 68.9 & 32.8 & 74.5 & 36.8 \\
\hline & FS Gomes & 25.4 & 89.4 & 46.2 & 76.1 & 37.1 & 82.8 & 41.6 \\
\hline & Ellis and George & 8.6 & 23.8 & 8.2 & 24.5 & 7.2 & 24.2 & 7.7 \\
\hline & Churchill & 33.9 & 64.2 & 37.1 & 75.5 & 41.8 & 69.8 & 39.4 \\
\hline
\end{tabular}

The Bingham and Herschel-Buckley models showed similar results. In laminar flow, using the $\mathrm{DH}_{2}$ correlation yielded a good prediction of the friction factor in the circular duct as well as, virtually, in every annular. For the turbulent flow, the Ellis and George (1977) correlation, associated with the $\mathrm{DH}_{2}$ correlation, showed good results in both annular and circular ducts.

Using the power law model, a satisfactory estimate was achieved for the friction factor in laminar flow in circular and annular ducts (using $\mathrm{DH}_{1}$ correlation). For the Power law model in the turbulent regime, the highlights are the Churchill (1977) and Ellis and George (1977) correlations, showing good results in annular and circular ducts.

\subsection{Impact on wellbore pressure predictions (case studies)}

The goal of this section is to illustrate the impacts of the analyzed set of correlations on pumping pressure in the evaluated systems. The effects of the rheological models on the pumping pressure were evaluated using the validated correlations on the numerical simulator of Petrobras Company in Brazil. The friction factor correlations used in the software for each fluid was chosen through the results presented in the previous sections of this paper and in those reported by Scheid et al. (2009).

\subsubsection{Case study 1 - ERW well}

This work compared the simulated results for pumping pressure of an onshore real deviated and extended-reach well (ERW) located in the state of Bahia (Brazil). The cemented stage is $800-\mathrm{m}$ deep. The casing has 7 inch of outer diameter and 6.3 inch of inner diameter. Because of well deviation, the frictional pressure loss is more evident than in a vertical well, having both the same length. This effect can be explained by the minimization of the hydrostatic pressure in deviated wells. In Table 6 it is possible to monitor the residence time of each fluid in the wellbore, as well as the volume and the average injection flow rate. Rheological parameters of the fluids used during well cementing are shown in Table 7. 
Table 6. Monitoring of fluid volume, flow rate, and residence time in the well.

\begin{tabular}{|c|c|c|c|c|c|}
\hline Fluids & Volume (bbl) & $\begin{array}{l}\text { Flow Rate } \\
\text { (bpm) }\end{array}$ & Time (min) & $\begin{array}{l}\text { Accumulated } \\
\text { time(min) }\end{array}$ & $\begin{array}{l}\text { Cumulative } \\
\text { volume (bbl) }\end{array}$ \\
\hline Spacer & 10.0 & 3.0 & 3.3 & 3.3 & 10.0 \\
\hline Pause & - & - & 1.5 & 4.8 & 10.0 \\
\hline Spacer & 10.0 & 3.0 & 3.3 & 8.2 & 20.0 \\
\hline Pause & - & - & 1.5 & 9.7 & 20.0 \\
\hline Spacer & 10.0 & 3.0 & 3.3 & 13.0 & 30.0 \\
\hline Pause & - & - & 1.5 & 14.5 & 30.0 \\
\hline Spacer & 20.0 & 3.0 & 6.7 & 21.2 & 50.0 \\
\hline Pause & - & - & 8.0 & 29.2 & 50.0 \\
\hline Slurry 1 & 5.0 & 2.0 & 2.5 & 31.7 & 55.0 \\
\hline Slurry 1 & 5.0 & 3.2 & 1.6 & 33.2 & 60.0 \\
\hline Slurry 1 & 40.0 & 4.0 & 10.0 & 43.2 & 100.0 \\
\hline Slurry 1 & 10.0 & 4.1 & 2.4 & 45.7 & 110.0 \\
\hline Slurry 1 & 64.0 & 4.2 & 15.2 & 60.9 & 174.0 \\
\hline Slurry 2 & 5.0 & 1.0 & 5.0 & 65.9 & 179.0 \\
\hline Pause & - & - & 2.0 & 67.9 & 179.0 \\
\hline Slurry 2 & 15.0 & 1.5 & 10.0 & 77.9 & 194.0 \\
\hline Slurry 2 & 10.0 & 2.0 & 5.0 & 82.9 & 204.0 \\
\hline Slurry 2 & 20.0 & 2.2 & 9.1 & 92.0 & 224.0 \\
\hline Slurry 2 & 15.0 & 1.5 & 10.0 & 102.0 & 239.0 \\
\hline Displacement Fluid & 25.0 & 2.0 & 12.5 & 114.5 & 264.0 \\
\hline Displacement Fluid & 10.0 & 2.5 & 4.0 & 118.5 & 274.0 \\
\hline Displacement Fluid & 15.0 & 3.0 & 5.0 & 123.5 & 289.0 \\
\hline Displacement Fluid & 25.0 & 3.9 & 6.4 & 129.9 & 314.0 \\
\hline Displacement Fluid & 15.0 & 3.0 & 5.0 & 134.9 & 329.0 \\
\hline Displacement Fluid & 7.4 & 2.0 & 3.7 & 138.6 & 336.4 \\
\hline
\end{tabular}

Table 7. Rheological parameters obtained for the fluids used in Case Study 1.

\begin{tabular}{|c|c|c|c|c|c|c|c|c|c|}
\hline \multirow[b]{2}{*}{ Fluids } & \multirow[b]{2}{*}{$\begin{array}{l}\text { Density } \\
\text { (lb/gal) }\end{array}$} & \multirow[b]{2}{*}{$\begin{array}{c}\mu \\
(\mathrm{cP})\end{array}$} & \multicolumn{2}{|c|}{ Power law } & \multicolumn{2}{|c|}{ Bingham } & \multicolumn{3}{|c|}{ Herschel-Buckley } \\
\hline & & & $\mathrm{n}$ & $\begin{array}{c}K \\
\text { (lbf.s }{ }^{n} / 100 f \\
\left.t^{2}\right)\end{array}$ & $\begin{array}{c}\mathrm{LE} \\
(\mathrm{lbf} / 100 \mathrm{f} \\
\left.\mathrm{t}^{2}\right)\end{array}$ & $\begin{array}{l}\text { VP } \\
(c P)\end{array}$ & $n$ & $\begin{array}{c}K \\
\left(\text { lbf.s }{ }^{n} / 100 f\right. \\
\left.t^{2}\right)\end{array}$ & $\begin{array}{c}\text { LE } \\
(\mathrm{lbf} / 100 f \\
\left.t^{2}\right)\end{array}$ \\
\hline $\begin{array}{l}\text { Spacer } \\
\text { Fluid }\end{array}$ & 8.3 & 1.0 & - & - & - & - & - & - & - \\
\hline $\begin{array}{l}\text { Cement } \\
\text { Slurry } 1\end{array}$ & 9.8 & - & 0.16 & 12.31 & 23.17 & 10.63 & 0.49 & 0.72 & 18.55 \\
\hline $\begin{array}{l}\text { Cement } \\
\text { Slurry } 2\end{array}$ & 11.0 & - & 0.62 & 1.18 & 3.10 & 63.79 & 1.00 & 0.20 & 0.80 \\
\hline $\begin{array}{l}\text { Displacement } \\
\text { Fluid }\end{array}$ & 10.4 & - & 0.98 & 0.23 & 0.80 & 96.14 & 0.75 & 0.76 & 6.12 \\
\hline
\end{tabular}

Fig. 4 presents the simulated cemented phase at $800 \mathrm{~m}$ from the beginning of the drilled well whereas Fig. 5 shows the whole trajectory of the deviated well.

Fig. 6 displays comparative results between simulated pumping pressures using different rheological models for cement slurry. All results are for laminar flow using the correspondent friction factor correlations chosen in the previous section.

All rheological models were evaluated in the calculation of pressure drop in the set of fluid flow fed into the well. Fig. 6 shows that the system 


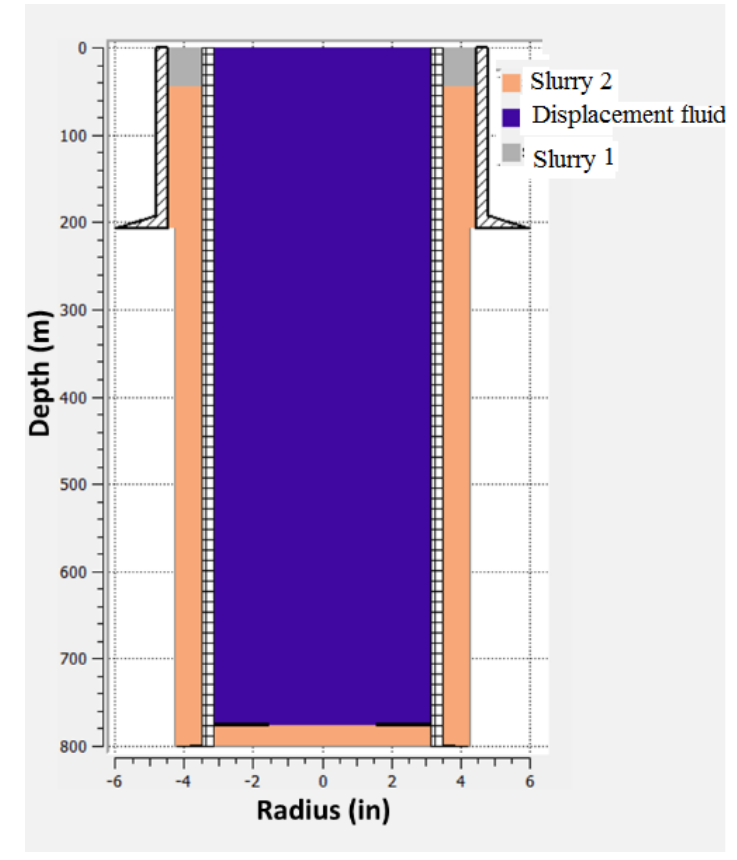

Figure 4. Wellbore trajectory: basic dimensions.

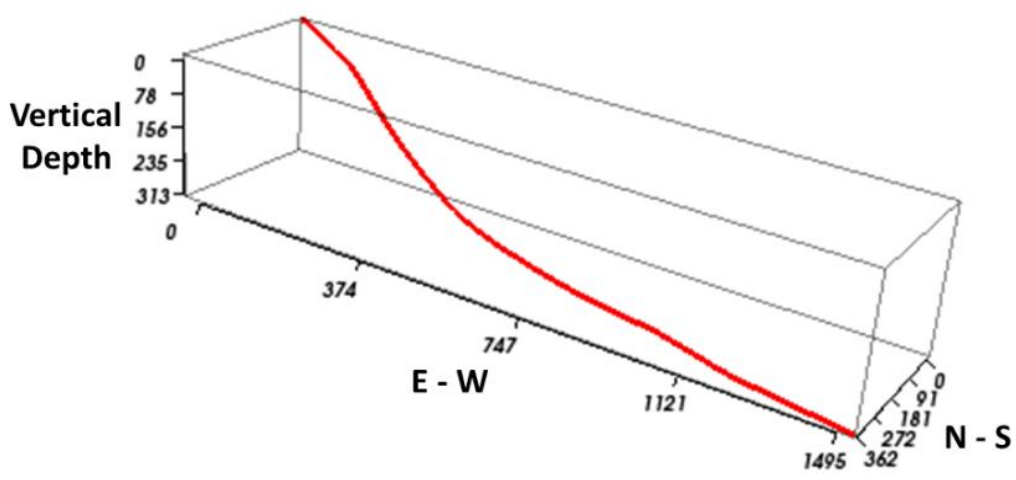

Figure 5. Wellbore trajectory using meter scale.

showed no sensitivity to the rheological models until $114.5 \mathrm{~min}$, as shown in Table 6. By that time, the volume of slurry inside the column prevailed on the system. In Fig. 6, the blue curve corresponds to the flow rate and the green curve to the pressure drop. Note that the green curve overlaps the other curves corresponding to each rheological model.

After $114.5 \mathrm{~min}$, due to the effect of cement slurry in the pressure drop curves (see Fig. 6), there is a discrimination between models if compared to experimental data. For this reason, it becomes clear how the rheological model can affects the simulated results.
In that case, one can observe that the effect of pressure drop due to cement slurries becomes more relevant when both slurries have their injection process in the completed wellbore (as shown in Table 6, about $114.5 \mathrm{~min}$ ). The effect of replacing equations set generates an average discrimination in simulated pressures around 12 and $5 \%$ for the Bingham and Power law models compared with the Herschel-Buckley.

Despite this disparity between the simulated and measured pressures, the average absolute percentage errors were 9.4, 8.6, and $11.0 \%$ for the Herschel-Buckley, Power Law, and Bingham 


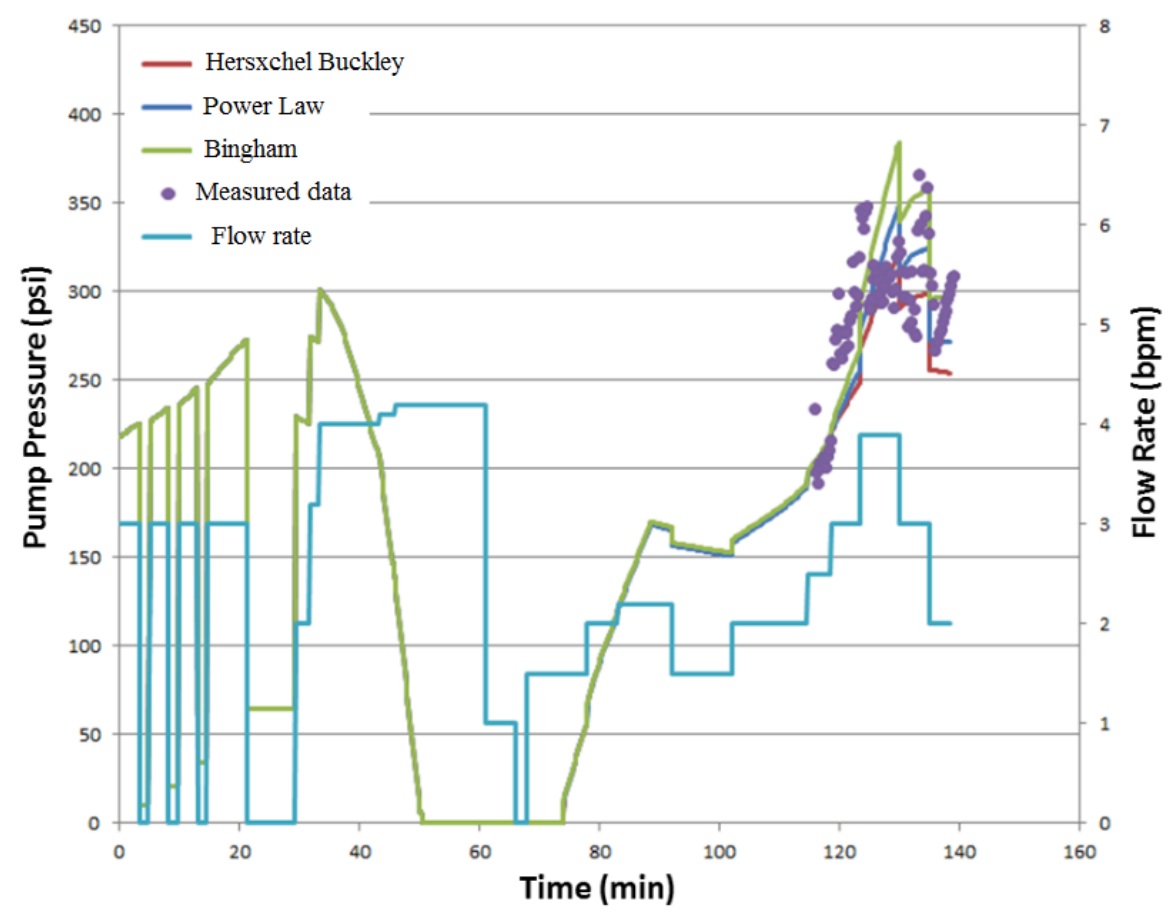

Figure 6. Monitoring simulated pumping pressure with the three rheological models assessed in this research.

models, respectively. The percentage errors obtained were relatively equivalent due to intense variation of the real field data. The hydrostatic pressure generated by the displacement fluid was the factor that compromised the evaluation before $114.5 \mathrm{~min}$. The high pumping pressure of this fluid minimizes the impact of replacing the rheological models over the global pressure drop of the system.

\subsubsection{Case study 2 - Campos basin well - narrow operational window}

In this second case study, the data are from deep water well with a narrow operational window located in the Campos Basin, Brazil. Table 8 shows the pumping sequence of each fluid in the wellbore, as well as the volume and the average injection flow rate, see Fig. 7. The rheological parameters of the fluids during well cementing operation are shown in Table 9.

Data on well trajectory and geometry are presented in Figs. 7 and 8 . Figure 7 shows the drilling fluid followed by the washer, then, followed by the spacer, followed by the cement slurry, and, finally, by the injection of the displacement fluid. Fig. 8 shows the whole trajectory of the well.

Table 8. Monitoring fluid volume, flow rate, and residence time in the well.

\begin{tabular}{lccccc}
\hline \multicolumn{1}{c}{ Fluids } & Volume $(\mathrm{bbl})$ & $\begin{array}{c}\text { Flow Rate } \\
(\mathrm{bpm})\end{array}$ & $\begin{array}{c}\text { Time } \\
(\mathrm{min})\end{array}$ & $\begin{array}{c}\text { Accumulated } \\
\text { time }(\mathrm{min})\end{array}$ & $\begin{array}{c}\text { Cumulative } \\
\text { volume (bbl) }\end{array}$ \\
\hline Washer & 70.0 & 8.0 & 8.8 & 8.8 & 70.0 \\
Pause & - & - & 10.0 & 18.8 & 70.0 \\
Spacer & 57.0 & 8.0 & 7.1 & 25.9 & 127.0 \\
Pause & - & - & 10.0 & 35.9 & 127.0 \\
Cement Slurry & 96.0 & 6.0 & 16.0 & 51.9 & 223.0 \\
Pause & - & - & 10.0 & 61.9 & 223.0 \\
Displacement Fluid & 55.0 & 6.0 & 9.2 & 71.0 & 278.0 \\
Pause & - & - & 10.0 & 81.0 & 278.0 \\
Displacement Fluid & 410.0 & 10.0 & 41.0 & 122.0 & 688.0 \\
Displacement Fluid & 51.1 & 5.0 & 10.2 & 132.3 & 739.1 \\
\hline
\end{tabular}


Table 9. Rheological parameters obtained for the fluids used in Case Study 2.

\begin{tabular}{|c|c|c|c|c|c|c|c|}
\hline \multirow[b]{2}{*}{ Fluids } & \multirow[b]{2}{*}{$\begin{array}{c}\text { Density(l } \\
\text { b/gal) }\end{array}$} & \multirow[b]{2}{*}{$\begin{array}{l}\mu, \\
(\mathrm{cP})\end{array}$} & \multicolumn{2}{|c|}{ power law } & \multicolumn{3}{|c|}{ Herschel-Buckley } \\
\hline & & & $\mathrm{n}$ & $\begin{array}{c}\mathrm{K} \\
\left(\text { lbf. } \mathrm{s}^{\mathrm{n}} / 100 f\right. \\
\left.\mathrm{t}^{2}\right) \\
\end{array}$ & $\mathrm{n}$ & $\begin{array}{c}\mathrm{K} \\
\text { (lbf.s }^{\mathrm{n}} / 100 f \\
\left.\mathrm{t}^{2}\right) \\
\end{array}$ & $\begin{array}{c}\mathrm{LE} \\
(\mathrm{lbf} / 100 \mathrm{f} \\
\left.\mathrm{t}^{2}\right) \\
\end{array}$ \\
\hline Washer Fluid & 6.7 & 1.0 & - & - & - & - & - \\
\hline Spacer Fluid & 11.4 & - & - & - & 0.70 & 0.49 & 3.52 \\
\hline Cement Slurry & 11.7 & - & - & - & 0.69 & 2.12 & 2.03 \\
\hline Drilling Fluid & 9.7 & - & 0.41 & 2.99 & - & - & - \\
\hline Displacement Fluid & 8.5 & 1.0 & - & - & - & - & - \\
\hline
\end{tabular}

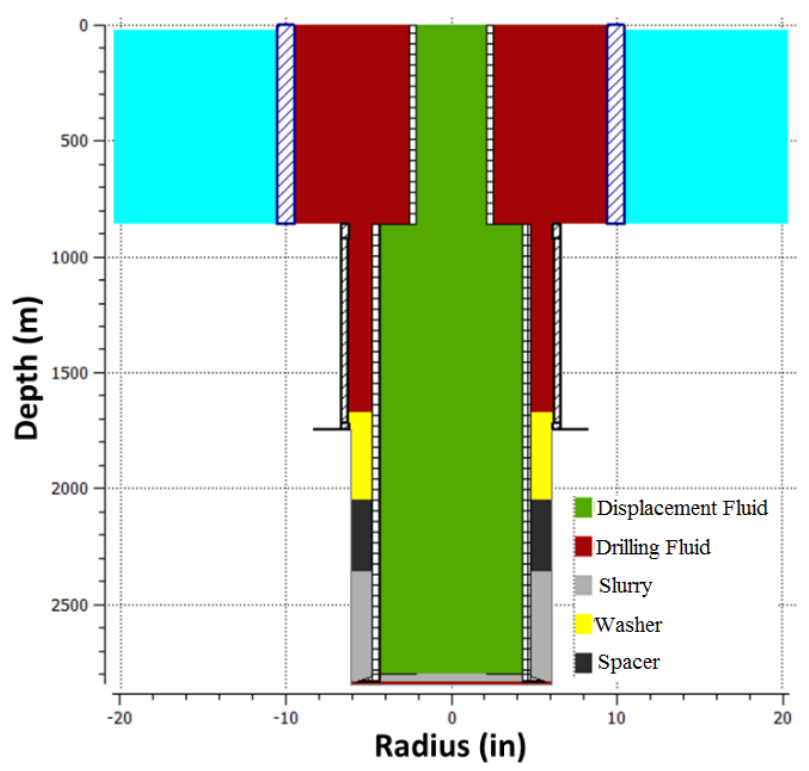

Figure 7. Wellbore trajectory: basic dimensions.

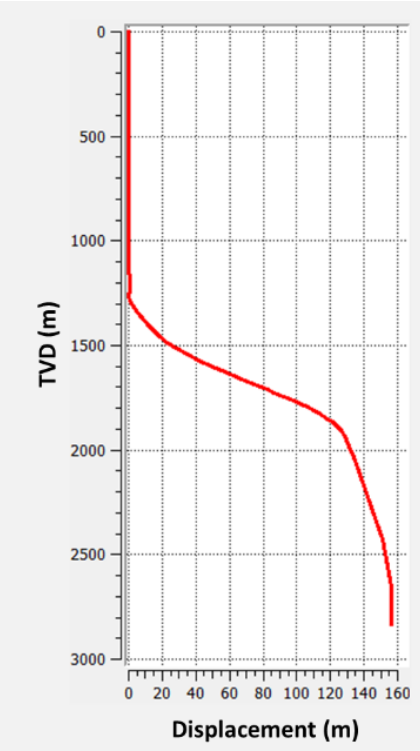

Figure 8. Wellbore trajectory using meter scale. 


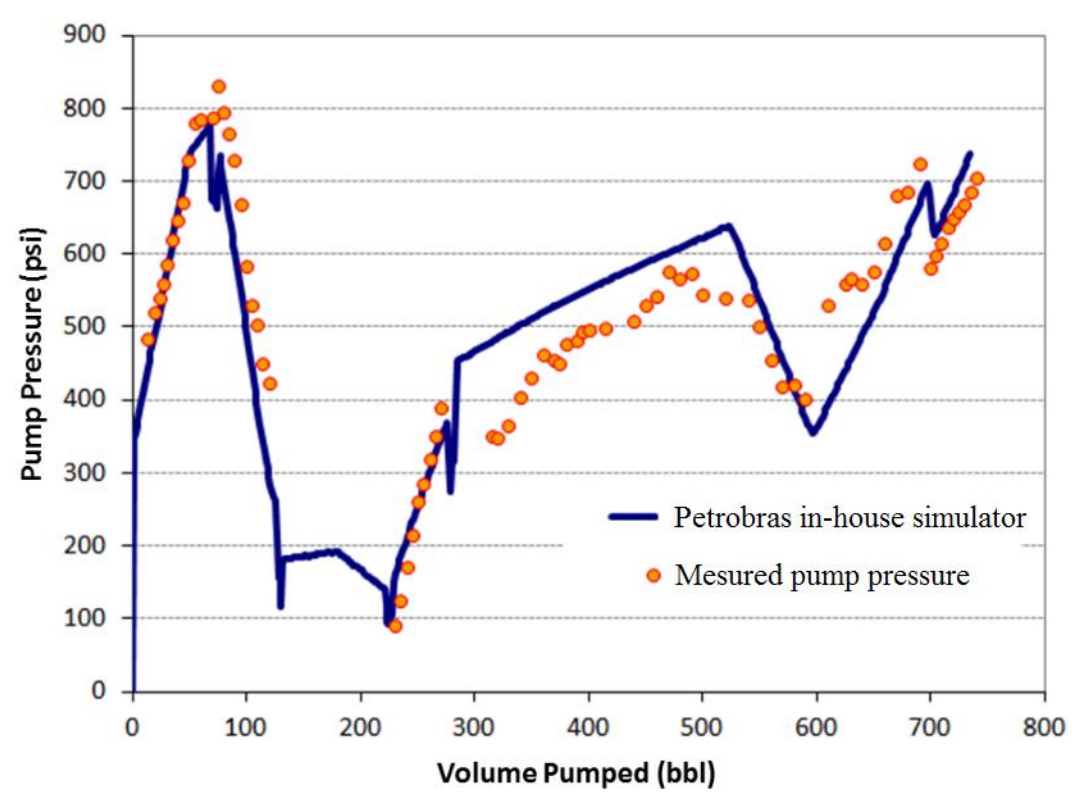

Figure 9. Monitoring simulated pumping pressure using the Herschel-Buckley model.

Fig. 9 displays comparative results between simulated and measured pumping pressures. In this case, the Herschel-Buckley model was used to simulate the pumping pressure of the cement slurry. Although the Power law model has presented the lowest error in the first case study, the Herschel-Buckley one was chosen because it showed good results in both experimental and simulated investigations for Case Study 1.

The analysis of Fig. 9 shows that there is a small deviation between experimental and simulated pumping pressure data with a mean absolute error of $13 \%$. Therefore, one can conclude that the set of equations evaluated and applied in the simulator was effective in predicting pressure drop. The good application results of the Herschel-Bulkley model agree with the experimental evaluations presented in this paper.

\section{CONCLUSIONS}

Based on the cement slurries analyzed, the Herschel-Buckley model was, in all cases, the one that best fitted the rheological data. In the set of rheological data for the cement slurries, the second best option appears to be the Bingham model. In the analysis of hydraulic diameter correlations, $\mathrm{DH}_{2}$ showed the best results for the cement slurries, using the Bingham and Herschel-Buckley models. In evaluating the friction factor correlations for the cement slurries in the laminar regime, there was a good prediction in the circular and annular duct using $\mathrm{DH}_{2}$ and the Bingham and Herschel-Buckley models. For the turbulent flow, the Ellis and George (1977) correlation associated with $\mathrm{DH}_{2}$, showed good results in both annular and circular ducts.

The results were validated in two case studies. In Case Study 1, which involves the simulation results of pumping pressure of an onshore real deviated and extended-reach well, the simulation results showed that the effect of the proposed set of equation generated a small average of standard deviation in simulated pressures. Although deviation from the predicted pressures was detected, the percentage errors were equivalent. This similarity is due to large variations in the real field data used. Furthermore, the high pumping pressure generated by the displacement fluid minimized the impact of the rheological model replacement over the global pressure drop of the system. Case Study 2 involves the simulation of a pumping sequence of many fluids in the wellbore as well as the volume and the average injection flow rate in deep water well with a narrow operational window. The results for Case 2 proved that the equations recommended can predict pressure drop satisfactorily. This outcome is not only for cement slurry but also for other pumped fluids, corroborating operational success in cementing in areas with narrow operational windows. 
The simulation results showed that the rheological model and friction factor affect pressure drop calculations.

\section{ACKNOWLEDGEMENTS}

The authors would like to thank CENPES (PETROBRAS Research Center) (4600293210) and Coordination for the Improvement of Higher Education Personnel (CAPES) for the financial support offered for the development of this project and the scientific support from members of Postgraduate Program in Chemical Engineering from Rural Federal University of Rio de Janeiro (PPGEQ/UFRRJ).

\section{NOMENCLATURE}

D Diameter, $m$

$D_{1} \quad$ Outer diameter of the inner tube, $m$

$D_{2}$ Inner diameter of the outer tube, $m$

$D_{\mathrm{H} 1}$ Hydraulic diameter (slot), $m$

$\mathrm{D}_{\mathrm{H} 2}$ Hydraulic diameter (hydraulic radius), $\mathrm{m}$

$f \quad$ Fanning friction factor

$f_{L} \quad$ Laminar friction factor

$f_{T} \quad$ Turbulent friction factor

He Hedstrom number

$\mathrm{He}_{\mathrm{B}}$ Hedstrom number - Bingham model

$\mathrm{He}_{\mathrm{HB}}$ Hedstrom number - Herschel-Buckley model

$k$ Consistency index - power law model, Pa. $\mathrm{s}^{\mathrm{n}}$

$k_{H B}$ Consistency index - Herschel-Buckley, Pa. $s^{n}$

$L \quad$ Length of the straight section, $m$

$\mathrm{LE}_{\mathrm{B}} \quad$ Yield stress for Bingham fluid, $\mathrm{Pa}$

$\mathrm{LE}_{\mathrm{HB}}$ Yield stress for Herschel-Buckley fluid, $\mathrm{Pa}$

$\mathrm{n} \quad$ Behavior index - power law model

$\mathrm{n}_{\text {Нв }}$ Behavior index - Herschel-Buckley model

Q Flow rate, $\mathrm{m}^{3} / \mathrm{s}$

$R_{H} \quad$ Hydraulic radius, $m$

$R^{2} \quad$ Correlation coefficient

Re Reynolds number

$\mathrm{Re}_{\mathrm{B}} \quad$ Generalized Reynolds number - Bingham

$\mathrm{Re}_{\mathrm{Hв}}$ Generalized Reynolds number - Herschel-Buckley

$R_{\mathrm{eP}} \quad$ Generalized Reynolds number - power law

$v$ or $\langle v\rangle$ Average velocity, $\mathrm{m} / \mathrm{s}$

$\mathrm{VP}_{\mathrm{B}}$ Bingham plastic viscosity, Pa.s

Greek letters

$\Delta \mathrm{P}$ Pressure drop, $\mathrm{Pa}$

$\rho \quad$ Fluid density, $\mathrm{kg} \cdot \mathrm{m}^{-3}$

$\varepsilon \quad$ Roughness of the pipe, $m$

$\gamma \quad$ Shear rate, $\mathrm{s}^{-1}$

$\lambda$ Equation's parameter, $s^{-1}$

$\tau \quad$ Shear stress, $\mathrm{Pa}$

$\tau_{\mathrm{w}} \quad$ Shear stress, $\mathrm{Pa}$

$\mu \quad$ Newtonian viscosity, $\mathrm{cP}$

\section{REFERENCES}

Bourgoyne Jr., A. T., Millheim, K. K., Chenevert, M. E., Young Jr, F. S. Applied Drilling Engineering. Richardson: Second printing, Society Of Petroleum Engineers, Texas, 1991.

Churchill, S. W. Friction factor equation spans all fluid flow regimes. Journal of Chemical Engineering, v. 84, p. 91-92, 1977.

Darby, R.; Melson, J. How to predict the friction factor for the flow of Bingham plastics. Journal of Chemical Engineering, v. 88(26), p. 59-61, 1981.

Darby, R.; Mun, R.; Boger, D. V. Predict friction loss in slurry pipes. Journal of Chemical Engineering, v.9, p. 116-119, 1992

Ellis, R. C.; George, D. S. Practical interpretation on rheology, annular displacing torces. How to avoid by passing mud during primary cementing. World Oil, p. 64-69, 1977.

Gomes, F. J. A. D. Hydraulic, power law models, calculation method using rational polynomial models. Proceedings of Technical meeting on software developing in drilling operations, CAPER/87, Salvador, Brazil, 1987. (in Portuguese)

Lake L. W.; Mitchel R.F. Petroleum Engineering Handbook. USA: Society of Petroleum Engineers, v. 2, Chapter 3, 2006.

Miranda, C. R. High packing cement slurries for oil wells - formulation process, rheological properties, mechanical and chemical resistance. Doctoral Thesis, Institute of Military Engineering of Rio de Janeiro, Rio de Janeiro, Brazil, 2008. (in Portuguese)

Nelson, E. B. Well Cementing. Houston: Schlumberger Educational Services; 1990.

Paraiso, E. C. H. Study of cement slurries flow in circular and concentric annular ducts. Master's dissertation, Federal Rural University of Rio de Janeiro; 2011. (in Portuguese)

Scheid, C. M.; Calçada, L. A.; Rocha, D. C.; Aranha, P. E.; Aragão, A. F. L.; Martins, A. L. Prediction of Pressure Losses in Drilling Fluids Flow in Circular and Annular Pipes and Accessories, Society of Petroleum Engineers, 2009. https://doi.org/10.2118/122072-ms

Tomita, Y. A. A study on non-Newtonian flow in pipe lines. Bulletin JSME, v.2, n.5, p. 10-16; 1959. https://doi.org/10.1299/isme1958.2.10 


\section{APPENDIX}

Table A.1. Evaluated friction factor correlations in laminar regime.

\begin{tabular}{|c|c|}
\hline Models & Equations \\
\hline Power Law & $\mathrm{f}=\frac{16}{\operatorname{Re}_{\mathrm{P}}} \quad \operatorname{Re}_{P}=\frac{D\langle v\rangle \rho}{k\left(\frac{8 v}{D}\right)^{n-1}\left(\frac{3 n+1}{4 n}\right)^{n}}$ \\
\hline Bingham & $\begin{aligned} f & =\frac{16}{\operatorname{Re}_{B}}\left[1+\frac{H e_{B}}{6 \operatorname{Re}_{B}}-\frac{H e_{B}^{4}}{3 f^{3} \operatorname{Re}_{B}^{7}}\right] \\
\operatorname{Re}_{B} & =\frac{D\langle v\rangle \rho}{V P_{B}} \quad H e_{B}=\frac{D^{2} \rho L E_{B}}{V P_{B}^{2}}\end{aligned}$ \\
\hline Herschel-Buckley & $\begin{array}{r}\mathrm{f}=\frac{2 \mathrm{He}_{\mathrm{HB}}}{\operatorname{Re}_{\mathrm{HB}}^{2}}+\frac{16}{\operatorname{Re}_{\mathrm{HB}}}[\mathrm{A}]^{-\mathrm{n}_{\mathrm{HB}}} \quad[A]=f\left[L E_{H B}, \tau_{w}, n_{H B}\right] \\
\operatorname{Re}_{H B}=\frac{8 D^{n_{H B}}\langle v\rangle^{2-n_{H B}} \rho}{k_{H B}\left[2\left(3 n_{H B}+1\right) / n_{H B}\right]^{n_{H B}}} \quad H e_{H B}=\operatorname{Re}_{H B}^{2} \frac{L E_{H B}}{\rho\langle v\rangle^{2}} \\
\frac{\mathrm{LE}_{\mathrm{HB}}}{\tau_{\mathrm{w}}}=2 \frac{\mathrm{He}_{\mathrm{HB}}}{\mathrm{f} \mathrm{Re}_{\mathrm{HB}}^{2}}\end{array}$ \\
\hline
\end{tabular}

Table A.2. Evaluated friction factor correlations in turbulent regime.

\begin{tabular}{|c|c|}
\hline Authors & Equations \\
\hline Gomes (1987) & $\begin{array}{c}\text { DMGomes } f=0.060 n^{0.462} \mathrm{Re}^{-0.223} \\
\text { OWGomes } f=0.069 n^{0.666} \mathrm{Re}^{-0.235} \\
\text { FSGomes } f=0.110 n^{0.616} \mathrm{Re}^{-0.287}\end{array}$ \\
\hline Darby and Melson (1981) & $f_{T}=\frac{10^{a}}{\mathrm{Re}^{0.290}} ; a=-1.378\left[1+0.14 \exp \left(-2.9 \times 10^{-5} \mathrm{He}\right)\right]$ \\
\hline Tomita (1959) & $\mathrm{f}=\lambda / 4$ Onde $\frac{1}{\sqrt{\lambda}}=2 \log \left(\operatorname{Re} \frac{\sqrt{\lambda}}{2}\right)-0,2$ \\
\hline Darby et al. (1992) & $f=\frac{10^{a}}{\operatorname{Re}^{0.193}} \quad a=-1.47\left[1+0.146 \exp \left(-2.9 .10^{-5} \mathrm{He}\right)\right]$ \\
\hline Ellis and George (1977) & $f=0.00454+0.645 \operatorname{Re}^{-0.70}$ \\
\hline Churchill (1977) & 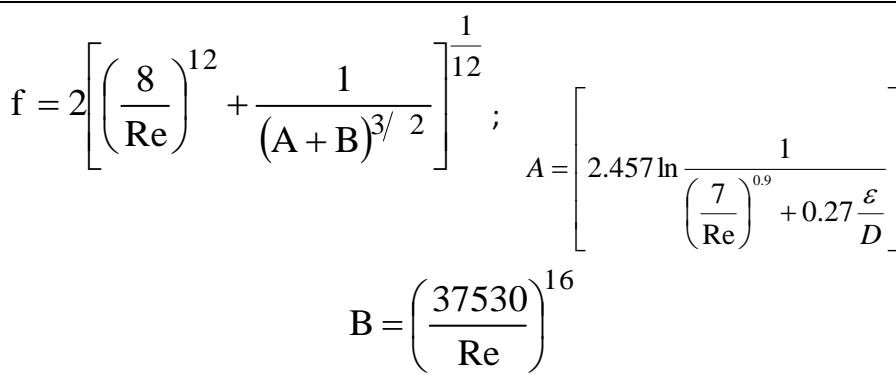 \\
\hline
\end{tabular}

